\title{
GABA Site Agonist Gaboxadol Induces Addiction-Predicting Persistent Changes in Ventral Tegmental Area Dopamine Neurons But Is Not Rewarding in Mice or Baboons
}

\author{
Elena Vashchinkina, ${ }^{1}$ Anne Panhelainen, ${ }^{1}$ Olga Yu. Vekovischeva, ${ }^{1}$ Teemu Aitta-aho, ${ }^{1}$ Bjarke Ebert, ${ }^{2}$ Nancy A. Ator, ${ }^{3}$ \\ and Esa R. Korpi ${ }^{1}$ \\ IInstitute of Biomedicine, Pharmacology, University of Helsinki, FI-00014 Helsinki, Finland, ${ }^{2 H}$. Lundbeck A/S, DK-2500 Copenhagen, Denmark, and \\ ${ }^{3}$ Division of Behavioral Biology, Psychiatry, and Behavioral Sciences, The Johns Hopkins School of Medicine, Baltimore, Maryland 21224-6823
}

\begin{abstract}
Dopamine neurons of the ventral tegmental area (VTA) are involved at early phases of drug addiction. Even the first in vivo dose of various abused drugs induces glutamate receptor plasticity at the excitatory synapses of these neurons. Benzodiazepines that suppress the inhibitory GABAergic interneurons in the VTA via facilitation of synaptic $\mathrm{GABA}_{\mathrm{A}}$ receptors have induced neuroplasticity in dopamine neurons due to this disinhibitory mechanism. Here, we have tested a non-benzodiazepine direct GABA site agonist 4,5,6,7-tetrahydroisoxazolol[4,5-c]pyridine-3-ol (THIP) (also known as gaboxadol) that acts preferentially via highaffinity extrasynaptic $\mathrm{GABA}_{\mathrm{A}}$ receptors. A single sedative dose of THIP $(6 \mathrm{mg} / \mathrm{kg})$ to mice induced glutamate receptor plasticity for at least $6 \mathrm{~d}$ after administration. Increased AMPA/NMDA receptor current ratio and increased frequency, amplitude, and rectification of AMPA receptor responses suggested persistent targeting of GluA2-lacking AMPA receptors in excitatory synapses of VTA dopamine neurons ex vivo after THIP administration. This effect was abolished in $\mathrm{GABA}_{\mathrm{A}}$ receptor $\delta^{-1-}$ mice, which have a loss of extrasynaptic $\mathrm{GABA}_{\mathrm{A}}$ receptors. In behavioral experiments, we found neither acute reinforcement in intravenous selfadministration sessions with THIP at relevant doses using a yoked control paradigm in mice nor in baboons using a standard paradigm for assessing drug abuse liability; nor was any place preference found after conditioning sessions with various doses of THIP but rather a persistent aversion in $6 \mathrm{mg} / \mathrm{kg}$ THIP-conditioned mice. In summary, we found that activation of extrasynaptic $\delta$-subunit-containing $\mathrm{GABA}_{\mathrm{A}}$ receptors leads to glutamate receptor plasticity of VTA dopamine neurons, but is not rewarding, and, instead, induces aversion.
\end{abstract}

\section{Introduction}

Dopamine (DA) neurons, originating from the ventral tegmental area (VTA) of midbrain and projecting to the nucleus accumbens and medial prefrontal cortex, are essential in processing rewarding signals (Wise and Bozarth, 1987; White, 1996; Wolf, 1998; Nestler, 2005; Kauer and Malenka, 2007; Wise, 2008). Particularly, DA neurons are excited by unexpected rewards (Schultz et al., 1997). Modulation of normal DA signaling also allows drugs of abuse to harness natural reward processing and to alter mechanisms mediating reward-driven learning and memory. There-

Received Sept. 14, 2011; revised Feb. 29, 2012; accepted Feb. 29, 2012.

Author contributions: E.V., A.P., B.E., N.A.A., and E.R.K. designed research; E.V., A.P., O.Y.V., T.A.-a., and N.A.A. performed research; E.V., A.P., O.Y.V., T.A.-a., N.A.A., and E.R.K. analyzed data; E.V., A.P., O.Y.V., T.A.-a., B.E., N.A.A., and E.R.K. wrote the paper.

This work was supported by the Academy of Finland (E.R.K.), The Sigrid Juselius Foundation (E.R.K.), the Finnish Foundation for Alcohol Studies (E.V., A.P.), and Helsinki Biomedical Graduate School (A.P.). We thank H. Lundbeck A/S for a donation of THIP (gaboxadol) for the mouse studies and for support of the baboon study (N.A.A.); Hartmut Lüddens, Vanessa Bockhardt, and Gregg Homanics for providing the $\mathrm{GABA}_{\mathrm{A}}$ receptor $\delta$ knock-out mouse line and instructions for genotyping; Heidi Pehkonen for skillful technical aid in the mouse studies; and Elizabeth Koehler and Samuel Womack for skillful technical aid in the baboon study.

Correspondence should be addressed to Esa R. Korpi, Institute of Biomedicine, Pharmacology, POB 63 (Haartmaninkatu 8), University of Helsinki, FI-00014 Helsinki, Finland. E-mail: esa.korpi@helsinki.fi.

DOI:10.1523/JNEUROSCI.4697-11.2012

Copyright $\odot 2012$ the authors $\quad 0270-6474 / 12 / 325310-11 \$ 15.00 / 0$ fore, addiction can be viewed as a result of maladaptive learning (Hyman, 2005; Kauer and Malenka, 2007). One of the mechanisms behind this might be the drug-induced synaptic plasticity in the DA system, analogous to the hippocampal synaptic plasticity considered important for learning and memory (Pastalkova et al., 2006; Whitlock et al., 2006; Bowers et al., 2010; Lüscher and Malenka, 2011).VTA plasticity has been thought to represent one of the first neuronal traces, common to different addictive drugs, lasting beyond the actual presence of drugs and their metabolites in the brain (Saal et al., 2003; Brown et al., 2010). Therefore, drug-induced plasticity in the VTA can be a hallmark of the early development of addiction.

The plasticity of glutamate synapses in VTA DA neurons has been observed after administration of single doses of several addictive drugs. A single drug injection can potentiate VTA DA neurons up to $7 \mathrm{~d}$ (Ungless et al., 2001; Saal et al., 2003; Heikkinen et al., 2009). Using ex vivo electrophysiological techniques, this plasticity can be monitored by, for example, AMPA/NMDA receptor current ratio and rectification index tests (Ungless et al., 2001; Tan et al., 2010). Similar glutamatergic transmission occurs in VTA DA neurons during cue-reward learning when dopamine neurons start to respond to reward-predicting cues instead of to actual reward (Stuber et al., 2008). Underlying mechanisms of the 
plasticity include formation of new GluA2-subunit-lacking AMPA receptors at the synaptic sites (Ungless et al., 2001; Borgland et al., 2004; Argilli et al., 2008) and a reduction of NMDA receptor activity (Mameli et al., 2011).

In the present study, we have established that glutamate receptor plasticity in the VTA DA neurons can be induced by a single administration of non-benzodiazepine drugs preferentially acting on extrasynaptic inhibitory $\mathrm{GABA}_{\mathrm{A}}$ receptors. Particularly, we reveal the neuroplasticity-inducing effects of 4,5,6,7-tetrahydroisoxazolol[4,5c] pyridine-3-ol (THIP) (gaboxadol), which is a GABA site agonist preferring extrasynaptic high-affinity $\mathrm{GABA}_{\mathrm{A}}$ receptors (Chandra et al., 2006, 2010; Stórustovu and Ebert, 2006). We show that the effect of THIP on VTA DA neuron plasticity is lost in $\mathrm{GABA}_{\mathrm{A}}$ receptor $\delta$-subunit-deficient mice (Mihalek et al., 1999) that are devoid of extrasynaptic benzodiazepine-insensitive $\mathrm{GABA}_{\mathrm{A}}$ receptors (Wei et al., 2003; Zhang et al., 2007). We also used behavioral tests of passive (mouse) and voluntary (mouse and baboon) drug administration to link THIP-induced plasticity with motivational processes.

\section{Materials and Methods}

\section{Animals}

For electrophysiological and THIP dose testing behavioral assays, we used 3- to 4-week-old transgenic Th-EGFP (male and female) mice (Gong et al., 2003). GABA receptor $\delta$-subunit knock-out $\left(\delta^{-l-}\right.$ ) and the littermate $\delta^{+/+}$mice (males and females) were used in electrophysiological experiments at the age of 3-4 weeks (Mihalek et al., 1999). Behavioral experiments trying to establish the addiction potential of THIP were performed with 8 - to 10 -week-old male C57BL/6J mice (Charles River). Th-EGFP mouse line expressing enhanced green fluorescent protein (EGFP) under the control of the tyrosine hydroxylase promoter was maintained as heterozygous. Heterozygous Th-EGFP males were backcrossed to inbred C57BL/6J female mice at least six generations. The animals were weaned at the age of $21 \mathrm{~d}$ and genotyped for the presence of EGFP by PCR. All mice were group housed under $12 \mathrm{~h} \mathrm{light/dark} \mathrm{cycle} \mathrm{with} \mathrm{food} \mathrm{and} \mathrm{water} \mathrm{available} \mathrm{ad} \mathrm{libitum.}$ All experimental procedures in mice were approved by the Southern Finland Provincial Government. Study of addiction potential in nonhuman primates was performed in three adult male baboons (Papio hamadryas anubis, olive baboons; Primate Imports). Weights were $38-40 \mathrm{~kg}$ for baboon CR, 32-33 kg for $\mathrm{HC}$, and 33-34 $\mathrm{kg}$ for SI. All had previous experience in assessment of one to six other compounds (almost exclusively ligands for the benzodiazepine site) under the procedures used in the present study. Details of housing and care were the same as those in the study by Ator et al. (2010). Experimental procedures in baboons were approved by The Johns Hopkins University Animal Care and Use Committee.

\section{Electrophysiology}

For electrophysiology, the mice were naive or injected intraperitoneally between 8:00 and 9:00 A.M. with either THIP $(1,3$, or $6 \mathrm{mg} / \mathrm{kg}$ ) or ethanol $(2 \mathrm{~g} / \mathrm{kg}, 10 \% \mathrm{w} / \mathrm{v})$ or a comparable volume of saline as a vehicle control, and decapitated $24 \mathrm{~h}$ to $6 \mathrm{~d}$ later. Drugs were administrated at a volume of $100 \mu \mathrm{l}$ (THIP) or $200 \mu \mathrm{l}$ (ethanol) per $10 \mathrm{~g}$ of body weight.

\section{Brain slice preparation}

Horizontal midbrain slices were prepared, as described previously (Heikkinen et al., 2009). Briefly, brains were quickly dissected out, and $225-\mu \mathrm{m}$-thick slices were cut and stored for at least $1 \mathrm{~h}$ at $37^{\circ} \mathrm{C}$ in carbogen-bubbled recovery solution containing the following (in $\mathrm{mm}$ ): $126 \mathrm{NaCl}, 21.4 \mathrm{NaHCO}_{3}, 2.5 \mathrm{KCl}, 1.2 \mathrm{NaH}_{2} \mathrm{PO}_{4}, 2.4 \mathrm{CaCl}_{2}, 1.2 \mathrm{MgSO}_{4}$, 11.1 D-glucose, and 0.4 ascorbic acid, pH 7.4 (Nugent et al., 2007). The slices were transferred to a recording chamber and submerged in carbogen-bubbled artificial CSF (ACSF) containing the following (in mM): $126 \mathrm{NaCl}, 18 \mathrm{NaHCO}_{3}, 1.6 \mathrm{KCl}, 1.2 \mathrm{NaH}_{2} \mathrm{PO}_{4}, 2.5 \mathrm{CaCl}_{2}, 1.2$ $\mathrm{MgCl}_{2}$, and $11 \mathrm{D}$-glucose.

\section{Electrophysiological recordings}

Measurement of synaptic responses was performed using whole-cell patch-clamp technique. In Th-EGFP mice, the DA neurons were visualized using a microscope (Olympus BX51WI) equipped with a filter for EGFP fluorescence channel (485/20 nm excitation filter) and a digital camera (Hamamatsu C8484). In $\delta^{-1-}$ and $\delta^{+/+}$mice, the DA neurons were identified if a clear $I_{\mathrm{h}}$ current was observed after voltage clamping cells from -70 to $-120 \mathrm{mV}$ in $10 \mathrm{mV}$ steps (Heikkinen et al., 2009). The currents were amplified (Multiclamp 700A; Molecular Devices), lowpass filtered at $1.6 \mathrm{kHz}$, and digitized at $20 \mathrm{kHz}$ (Molecular Devices). Electrodes had a resistance of 3-5 $\mathrm{M} \Omega$ when filled with the following (in mM; $\mathrm{pH}$ adjusted to $7.2-7.25$ and osmolarity to $280 \mathrm{mOsm}$ ): 130 cesium methanesulfonate, 10 HEPES, 0.5 EGTA, $8 \mathrm{NaCl}$, 5 QX314, 4 MgATP, 0.3 MgGTP, and 10 BAPTA for EPSC recordings (Heikkinen et al., 2009); and 30 potassium-gluconate, $100 \mathrm{KCl}, 4 \mathrm{MgCl}_{2}, 1.1$ EGTA, 5 HEPES, 3.4 $\mathrm{Na}_{2} \mathrm{ATP}, 10$ creatine-phosphate, and $0.1 \mathrm{Na}_{3} \mathrm{GTP}$ for sIPSC recordings (Tan et al., 2010). The access and membrane resistances were monitored throughout the experiment. Recordings were discarded if the access resistance changed $>20 \%$ during the experiment.

\section{AMPA/NMDA receptor current ratio}

To assess AMPA/NMDA receptor current ratio of VTA DA neurons, EPSCs were induced by stimulating glutamatergic afferents at $0.1 \mathrm{kHz}$ frequency using bipolar stimulus electrode. Neurons were clamped at $+40 \mathrm{mV}$ in the presence $\mathrm{GABA}_{\mathrm{A}}$ receptor blocker picrotoxin $(100 \mu \mathrm{M})$. EPSCs were recorded for $10 \mathrm{~min}$ before and after the application of NMDA receptor blocker D-(-)-2-amino-5-phosphonopentanoic acid (AP5) $(50 \mu \mathrm{M})$. The ratio was calculated by dividing the peak amplitude of AMPA receptor current with that of NMDA receptor current. AMPA current was averaged from 30 EPSCs recorded in the presence of AP5. NMDA current component, in turn, was calculated by subtracting the AMPA current from the total current detected in the absence of AP5 (Ungless et al., 2001; Saal et al., 2003; Heikkinen et al., 2009).

\section{mEPSC and sIPSC recordings, paired-pulse ratio, and} rectification index

VTA DA neurons were clamped at $-70 \mathrm{mV}$ at $30-32^{\circ} \mathrm{C}$. Spontaneous AMPA receptor-mediated miniature EPSCs (mEPSCs) were recorded for 5 min in the presence of tetrodotoxin $(1 \mu \mathrm{M})$, picrotoxin $(100 \mu \mathrm{M})$, and AP5 $(50 \mu \mathrm{M})$. Spontaneous $\mathrm{GABA}_{\mathrm{A}}$ receptor-mediated IPSCs (sIPSCs) were recorded for $5 \mathrm{~min}$ before, during, and after bath application of $1 \mu \mathrm{M}$ THIP at the continuous presence of kynurenic acid ( $2 \mathrm{~mm}$ ). sIPSCs were abolished by $100 \mu \mathrm{M}$ picrotoxin (data not shown). Series resistance was compensated by $70 \%$. Recorded events were filtered at $1.6 \mathrm{kHz}$, digitized at $20 \mathrm{kHz}$, and analyzed automatically with Mini Analysis program (Synaptosoft) with an 8 pA amplitude threshold, and then all qualified events were visually verified according to their rise and decay times.

Recordings of evoked AMPAR-EPSCs were performed in the presence of picrotoxin $(100 \mu \mathrm{M})$ and AP5 $(50 \mu \mathrm{M})$. Paired-pulse ratio was determined by giving two stimuli at $50 \%$ of maximal response. The intervals between two stimuli were 20,50, and $100 \mathrm{~ms}$, and the recordings at each interval continued for $5 \mathrm{~min}$ at $0.1 \mathrm{kHz}$. The ratio was calculated as a ratio between peak amplitudes of the second averaged response to the first one. Recordings for the estimation of rectification indices were performed using freshly made spermine $(100 \mu \mathrm{M})$ in the pipette solution, and AMPAR-EPSCs were evoked at holding potentials of -70 and +40 $\mathrm{mV}$. The rectification index was calculated as the ratio between evoked AMPAR-EPSC peak amplitudes at $-70 \mathrm{mV}$ to those at $+40 \mathrm{mV}$.

Th-EGFP transgenic mouse line (Gong et al., 2003) was used to obtain heterogeneous population of VTA DA neurons independently on their different electrophysiological and molecular properties (Margolis et al., 2006; Lammel et al., 2008, 2011). In a post hoc manner after the recordings, anatomical localization of the VTA DA neurons in dorsoventral and rostrocaudal dimensions was determined from photomicrographs according to mouse brain atlas (Franklin and Paxinos, 2008) blind to the responses of individual neurons: ventral VTA was corresponded to $-4.56 \mathrm{~mm}$ and dorsal VTA to $-4.12 \mathrm{~mm}$ from the brain surface of the adult mouse. 


\section{Behavioral experiments}

Spontaneous locomotor activity. Effects of THIP $(1,3$, and $6 \mathrm{mg} / \mathrm{kg})$ on locomotor activity were tested $1.5 \mathrm{~h}$ immediately after acute injection (intraperitoneal). Effects of $6 \mathrm{mg} / \mathrm{kg}$ THIP on locomotor activity was estimated also at $24 \mathrm{~h}$ after the injection. Young mice were adapted to the experimental room for $2 \mathrm{~h}$, after which their locomotor activities were monitored individually in Plexiglas cages $(45 \times 22.5 \times 15 \mathrm{~cm}$; Tecniplast) by Ethovision Color-Pro 3.1 video-tracking system (Noldus Information Technology) (Heikkinen et al., 2009).

Intravenous drug self-administration in mice. The self-administration (SA) procedure in adult mice was based on one that has been used as a rapid screening procedure to evaluate drug reinforcement (Criswell and Ridings, 1983; Vekovischeva et al., 2004). The SA apparatus (RITEC) consisted of four identical opaque plastic chambers $(8 \times 8 \times 8 \mathrm{~cm})$. Each chamber was fitted with an infrared sensor and a nose-poke hole $(1.5 \mathrm{~cm})$ on the frontal wall and a vertical slot $(5 \mathrm{~mm})$ at the bottom of the back wall for extending and fixing the tail. Mice were placed into the individual chambers so that their tails were taped outside the chambers. From that position they could easily reach the holes. Opaque covers prevented the mice from moving out of the chambers. SA was determined in mouse pairs (active and yoked control). The pairs were matched based on similarity of nose poke activity during $10 \mathrm{~min}$ pretests. Within $1 \mathrm{~h}$ after the pretest, the matched pairs were placed into the neighboring chambers. Needles (27 ga) connected to $1 \mathrm{ml}$ syringes in a two-syringe infusion pump were inserted into the lateral tail vein of each animal. During a 20 min test, each nose poke of the active mouse resulted in a simultaneous infusion of the same fluid ( $1.7 \mu \mathrm{l} ; 1 \mathrm{~s}$ duration) to both active and yoked mice. Nose pokes of the yoked mouse were counted as well, but did not result in an infusion. As a measure of reinforcement effect, $R$ factor was calculated as the difference between the logarithm $\left(\log _{10}\right)$ of the ratio between cumulative numbers of nose pokes by active and yoked mice during the SA session and the logarithm of the ratio of their nose pokes during the pretest session (Kuzmin et al., 1994). Effects of the drug were considered aversive, reinforcing or neutral when the $R$ factor was negative, positive, or close to zero, respectively. The following concentrations of the drugs were tested: D-amphetamine $(0.5 \mathrm{mg} / \mathrm{ml})$, THIP $(0.1,0.5,1$, and $3 \mathrm{mg} / \mathrm{ml}$ ).

Intravenous self-administration in baboons. The equipment and procedures, including animal care, were the same as those described by Ator et al. (2010) and standard for abuse liability assessments (Ator and Griffiths, 2003). Briefly, the baboons' home cages had been outfitted with an intelligence panel equipped with cue lights and operanda, which was interfaced to computer control in an adjacent room. The cages were not enclosed and the baboons could see and hear other baboons housed in the same area. Each baboon had a chronically indwelling intravenous catheter that exited in the midscapular region and was protected by a tether/vest system that permitted free movement within the cage. Experimental conditions were in effect $24 \mathrm{~h} / \mathrm{d}$ during study of each dose. Data were recorded at approximately 8:30 A.M. daily, and any drug changes were made at that time (but with no interruption of the behavioral program). Onset of a $5 \mathrm{~s}$ tone and cue light were correlated with availability of a self-injection dependent on completion of the response requirement of 160 operations of a plunger device. Completion of the requirement initiated operation of a peristaltic pump that delivered the drug dose (5 $\mathrm{ml}$ across $\sim 90 \mathrm{~s}$ ) and began a $3 \mathrm{~h}$ time-out. Maximum possible selfinjections $/ 24 \mathrm{~h}$ was 8 . Food pellets ( $1 \mathrm{~g}$ banana-flavored pellets; Bio-Serv) were available $24 \mathrm{~h} / \mathrm{d}$ under a response requirement of 20 or 30 responses per pellet, depending on the baboon; two pieces of fresh fruit were delivered around 11:00 A.M. each day. Under the single-subject design that was used, each baboon served as his own control and replication across subjects determined generality of the finding. A standard baseline substitution procedure was used in which each test dose was substituted for a dose of cocaine $(0.32 \mathrm{mg} / \mathrm{kg})$ that reliably maintained high rates of self-injection in each baboon. The cocaine baseline was in effect for a minimum of $3 \mathrm{~d}$ with performance at the criterion rate of $6-8 / 24 \mathrm{~h}$ before each test condition. Each dose (THIP, 0.1, 0.18, 0.32, and 1.0 $\mathrm{mg} / \mathrm{kg}$, or the saline vehicle, studied in a mixed order within and across baboons) was available for self-injection for $15 \mathrm{~d}$. A physical examination, weighing, and care of the catheter exit site occurred at the end of the
$15 \mathrm{~d}$ before return to the cocaine baseline condition for study of the next THIP dose. A dose of triazolam $(0.01 \mathrm{mg} / \mathrm{kg})$ known to be reinforcing in baboons under the same study conditions in our laboratory (Griffiths et al., 1991) was made available as a GABAergic positive control in baboon SI after study of THIP; this drug had been studied earlier in the other two baboons. Drug reinforcement was defined as a mean rate of self-injection in the last $5 \mathrm{~d}$ of drug availability that was $>2$ SDs higher than that maintained by the saline vehicle in its last $5 \mathrm{~d}$ of availability (i.e., analogous to a one-tailed test).

Place conditioning. The procedure was performed in eight Plexiglas cages $(45 \times 22.5 \times 15 \mathrm{~cm}$; Tecniplast $)$ covered with transparent Plexiglas lids with ventilation holes (Nuutinen et al., 2010). Two types of floor material were used as conditioning stimuli: (1) plastic material consisting of $1.2-\mathrm{cm}$-wide flat bars separated by $0.5 \mathrm{~cm}$ gaps, and (2) metal grid material of $1 \mathrm{~mm}$ spaced wire mesh. The materials had been preselected on the basis of 15 min preliminary tests for material preference using a separate batch of naive mice and several different floor material choice pairs. The animals showed no preference for either one of the above floor materials (data not shown), which allowed us to follow the unbiased conditioned place preference procedure (Cunningham et al., 2006) consisting of three phases: habituation, conditioning, and preference testing. Two independent batches of adult mice were used for these experiments.

In the habituation phase, the mice were weighed, injected with saline, and placed into conditioning cages without the conditioning-floor materials. The conditioning phase consisted of $30 \mathrm{~min}$ presentations of floor materials that were differentially paired with THIP and saline pretreatments. The mice were randomly assigned to one of the two conditioning subgroups (metal+ and metal-). Mice in the metal + subgroup received THIP paired with the metal grid floor [conditioning stimulus $+(\mathrm{CS}+)$ trial] and saline paired with the plastic floor (CS-). Mice in the metalsubgroup received THIP paired with the plastic floor $(\mathrm{CS}+)$ and saline paired with the metal grid floor (CS-). Mice received four CS + and four $\mathrm{CS}-$ trials on alternating days, resulting in eight conditioning trials in total. After the first $4 \mathrm{~d}$, there was a $2 \mathrm{~d}$ break. Each group was counterbalanced for the direction of the floor materials inside the cages and for the order the trials were presented.

The place preference test (30 min) was performed $24 \mathrm{~h}, 11 \mathrm{~d}$, and $30 \mathrm{~d}$ after the last conditioning trial. Then the cage floor was covered half and half with plastic and metal grid materials, thereby bisecting it into two distinct virtual zones where the mice could move according to their preference. The animals were injected with saline and then placed in the center of the cage. Spatial orientation of the materials was counterbalanced within each group. Time spent on the metal grid was used as the primary dependent variable in data analysis. Locomotor activity and location were determined by Ethovision Color-Pro 3.1 video-tracking system. Between the trials, all cages and floor materials were thoroughly washed with water and dried to remove odors. The mice were habituated to the experimental room for $1 \mathrm{~h}$ before the testing. The experiments were performed between 8:00 and 12:00 A.M.

\section{Drugs}

THIP (gaboxadol hydrochloride; H. Lundbeck A/S), D-amphetamine sulfate (Dexedrine; GlaxoSmithKline), ethanol (Altia Oyj), and cocaine hydrochloride (Sigma-Aldrich) were dissolved in $0.9 \%$ saline for intraperitoneal and intravenous injections. Triazolam (Upjohn) was dissolved in propylene glycol and diluted by one-half with $0.9 \%$ saline. All stock solutions for mice were prepared on the day of the treatment. Stock solutions of picrotoxin, D- $(-)$-2-amino-5-phosphonopentanoic acid (AP5), tetrodotoxin (all from Tocris Bioscience), and THIP were diluted in ACSF, and added to perfusion medium when needed. Solutions for baboons were prepared and filter sterilized ( $0.22 \mu \mathrm{m}$ filters; Millipore) just before each test condition and replenished as needed.

\section{Statistical analyses}

Statistical analysis was performed using Prism 5.0 software (GraphPad Software). Statistical significance of the differences between data groups with equal variances was assessed with $t$ test or one-way ANOVA followed by Dunnett's or Bonferroni's posttest $(p<0.05)$. Nonparametric Mann-Whitney test or Kruskal-Wallis test followed by Dunn's multiplecomparison test were used with data with unequal variances. 
A

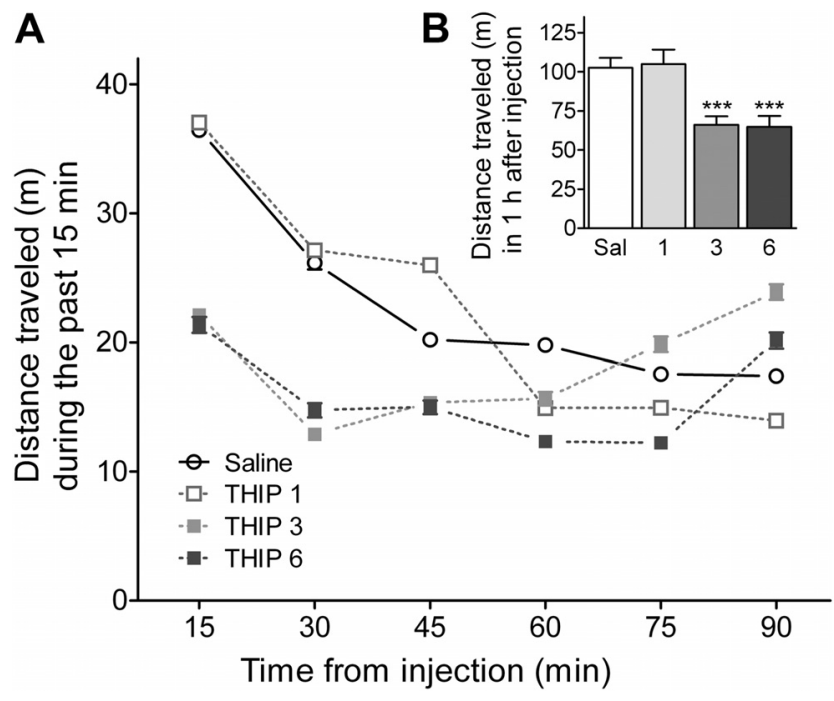

Figure 1. Time course of the effects of preferential extrasynaptic $G A B A_{A}$ receptor agonist THIP on spontaneous locomotor activity in young mice. $A$, Locomotor activity after acute injection of THIP ( $1 \mathrm{mg} / \mathrm{kg}, n=9 ; 3 \mathrm{mg} / \mathrm{kg}, n=20 ; 6 \mathrm{mg} / \mathrm{kg}, n=21)$ and saline $(n=22)$ in Th-EGFP mice (3- 4 weeks of age). The data are given as the mean distance traveled for $15 \mathrm{~min}$ periods preceding the time points (SEM values are within the symbols). $\boldsymbol{B}$, Cumulative locomotor activity for 60 min after injection for the mice shown in $A .{ }^{* * *} p<0.001$ for the significance of difference from saline group (ANOVA followed by Bonferroni's test). Data are presented as mean distance traveled + SEM.

\section{Results}

Effects of THIP on locomotor activity of mice

We searched for slightly sedative doses of THIP after acute injections and found that THIP at 3 and $6 \mathrm{mg} / \mathrm{kg}$ produced a transient reduction in locomotor activity of young mice, while $1 \mathrm{mg} / \mathrm{kg}$ dose of THIP did not affect the activity (Fig. 1A). The drug effects lasted for 45-60 min. A $1 \mathrm{~h}$ measure of cumulative locomotor activities was decreased $\left(F_{(3,68)}=10.24 ; p<0.0001\right)$ by both higher doses of THIP compared with saline (Fig. $1 B$ ). The THIPreduced activity returned to the baseline by $90 \mathrm{~min}$ after the injections (Fig. $1 \mathrm{~A}$ ) and remained at the saline level also at $24 \mathrm{~h}$ after $6 \mathrm{mg} / \mathrm{kg}$ THIP [14.6 $\pm 0.5 \mathrm{~m} / 45 \mathrm{~min}(n=18)$ vs $13.8 \pm 0.4$ $\mathrm{m} / 45 \mathrm{~min}(n=26)$ for saline- and THIP-treated mice, respectively; $p>0.05, t$ test]. There were no sex differences in the locomotor activity acutely or $24 \mathrm{~h}$ after the THIP treatment (cumulative distance: $F_{(1,45)}=2.76, p>0.05$, and $F_{(1,51)}=0.50, p>$ 0.05 , respectively).

\section{Single in vivo doses of THIP induce long-lasting potentiation in the VTA DA neurons}

In VTA DA neurons of midbrain slices from THIP- and ethanoltreated mice obtained $24 \mathrm{~h}$ after the injection, the peak height ratios between evoked AMPA and NMDA receptor-mediated excitatory currents were significantly higher than those in neurons from saline-treated mice (Fig. 2A,B; Kruskal-Wallis statistic, $16.04 ; p=0.003)$. THIP produced a dose-dependent increase in the ratio, as the dose of $6 \mathrm{mg} / \mathrm{kg}$ was different from the saline values, while the 1 and $3 \mathrm{mg} / \mathrm{kg}$ doses were not. The effect of THIP at $6 \mathrm{mg} / \mathrm{kg}$ was similar to the effect of ethanol at $2 \mathrm{~g} / \mathrm{kg}$, the ethanol results being in agreement with those of Heikkinen et al. (2009) (Fig. 2B).

In the above experiments, DA neurons were identified by the presence of fluorescent marker EGFP expressed under tyrosine hydroxylase gene promoter, and not by the magnitude of $I_{\mathrm{h}}$ current (Margolis et al., 2006; Lammel et al., 2008). This strategy
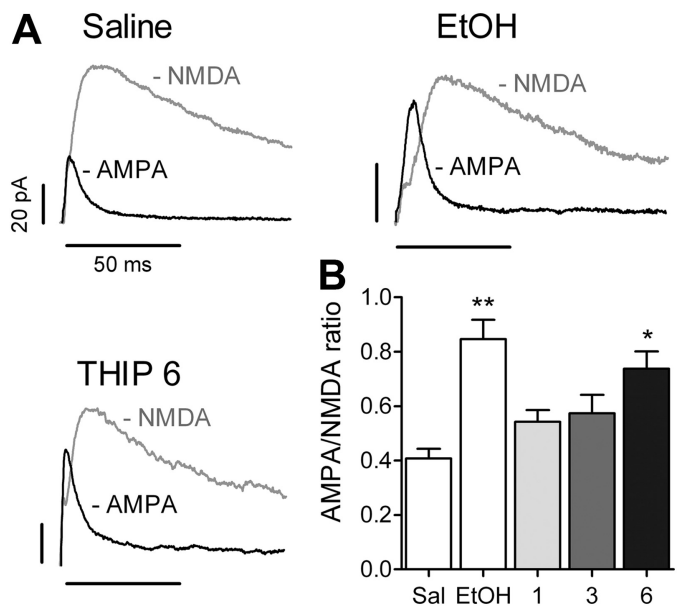

Figure 2. A single administration of THIP increased the AMPA/NMDA receptor current ratio in VTA DA neurons of midbrain slices obtained ex vivo $24 \mathrm{~h}$ after the drug injection. $A$, Representative examples of AMPA and NMDA receptor-mediated current traces for saline-, ethanol (EtOH) (2 g/kg)-, and THIP (6 mg/kg)-treated transgenic Th-EGFP young mice. B, AMPA/NMDA receptor ratios for saline ( $n=11$, where $n$ is the number of tested animals), $\mathrm{EtOH}(n=7)$, and THIP ( $1 \mathrm{mg} / \mathrm{kg}, n=7 ; 3 \mathrm{mg} / \mathrm{kg}, n=9 ; 6 \mathrm{mg} / \mathrm{kg}, n=21)$ are shown as average bars (+SEM). ${ }^{*} p<0.05$ and ${ }^{* *} p<0.01$ for the significance of the difference from saline group (KruskalWallis test followed by Dunn's test).

allowed evaluation of overall population of VTA DA neurons. We found that both $I_{\mathrm{h}}$ current-positive and -negative EGFP-labeled cells had similar responses to THIP treatment (data not shown) $(p>0.05)$. Furthermore, in the analysis of recordings according to cellular localizations after the experiments had been performed, no statistically significant differences $(p>0.05)$ after THIP treatment were observed in the AMPA/NMDA ratios between the ventral and dorsal VTA DA neurons (Fig. $3 A, B ; n=$ $6-13$ cells per group) nor between the caudal and rostral VTA DA neurons (Fig. $3 A, C ; n=7-11$ cells per group).

The effect of THIP administration lasted long, as the significant increase $(p<0.05)$ in the AMPA/NMDA ratio was still evident at least $6 \mathrm{~d}$ after the single $6 \mathrm{mg} / \mathrm{kg}$ THIP injection (Fig. $4 \mathrm{~A}$; treatment effect, $F_{(1,26)}=80.81, p<0.0001$, two-way ANOVA). The controls examined at each time point $(1,4$, and $6 \mathrm{~d}$ after the saline injection; $n=3-4$ mice in each group) did not differ significantly from one another (Fig. $4 A ; p>0.05$ ).

\section{Mechanisms of THIP-induced glutamate plasticity}

To investigate possible mechanisms of THIP-induced potentiation, we first examined the paired-pulse ratio in the VTA DA neurons. This method has been used at various synapses to assess the possible presynaptic mechanism of long-term plasticity (Mallart and Martin, 1968; Maren and Fanselow, 1995). Increased paired-pulse ratio typically implies a decrease in the probability of neurotransmitter release and vice versa. We compared the evoked AMPAR responses to paired pulses at different time intervals in neurons from saline- and $6 \mathrm{mg} / \mathrm{kg}$ THIP-treated mice. The paired-pulse ratios in each case were close to 1.0 and did not differ between the THIP- and saline-treated groups (Fig. $4 B ; p>0.05$ ).

Second, we examined whether THIP administration modifies AMPA receptor responses in the VTA DA neurons. Spontaneous miniature AMPA receptor-mediated EPSCs (mEPSCs) were recorded in the VTA DA neurons from saline- and $6 \mathrm{mg} / \mathrm{kg}$ THIPtreated mice. The amplitudes of the mEPSCs were increased (Fig. $4 D ; p<0.001$, Mann-Whitney test), and the interevent intervals 
were decreased after THIP treatment (Fig. $4 E ; p<0.001)$ indicating that THIP administration induced an increase in the amplitudes and frequency of postsynaptic AMPA receptor-mediated mEPSCs. These changes can also be seen in the cumulative probability plots (Fig. $4 D, E$ ).

Third, we tested the $I-V$ relationships of AMPAR EPSCs and calculated the rectification index since different drugs of abuse, including the benzodiazepines, induce potentiation in the VTA DA neurons through insertion of new GluA2-lacking receptors (Bellone and Lüscher, 2006; Tan et al., 2010). This can be seen as increased rectification at positive holding potentials when the pipette solution contains polyamines that selectively block the GluA2lacking receptors (Dingledine et al., 1999). We found that the normalized currents at the $+40 \mathrm{mV}$ holding potential were decreased in VTA DA neurons obtained $24 \mathrm{~h}$ after $6 \mathrm{mg} / \mathrm{kg}$ THIP administration compared with those obtained from saline-treated mice (Fig. $5 A, B ; p<$ 0.05, Mann-Whitney test) and that the calculated rectification indexes were higher for THIP-treated neurons $(3.3 \pm$ $0.4, n=6$, vs $2.1 \pm 0.1, n=6 ; p<0.01)$.

Finally, direct effects of THIP on VTA DA neurons were tested in acute midbrain slices of young Th-EGFP mice and bath application of $1 \mu \mathrm{M}$ THIP. The application of THIP in vitro reduced the $\mathrm{GABA}_{\mathrm{A}}$ receptor-mediated sIPSC frequency and amplitude (Fig. 6A). This can be seen in cumulative probability plots as shifts to lower amplitudes and longer interevent intervals of the sIPSCs in the presence of THIP (Fig. 6B; $p<0.001$, Mann-Whitney test). The THIP concentration applied here $(1 \mu \mathrm{M})$ corresponds to brain levels of THIP after an intraperitoneal dose of 6 $\mathrm{mg} / \mathrm{kg}$ (Cremers and Ebert, 2007).

These results suggest that the AMPA responses are increased after THIP administration, at least in part, by insertion of new GluA2-subunit-lacking AMPA receptors with a mechanism consistent with disinhibition of VTA DA neurons.

\section{THIP-induced glutamate plasticity in the VTA DA neurons is} abolished in $\delta^{-1-}$ mice

THIP acts preferentially on $\delta$-subunit-containing extrasynaptic $\mathrm{GABA}_{\mathrm{A}}$ receptors both in recombinant receptors and animal models, THIP acting as a superagonist with efficacy higher than that for GABA (Brown et al., 2002; Krogsgaard-Larsen et al., 2004; Chandra et al., 2006, 2010; Stórustovu and Ebert, 2006). Recently, functional extrasynaptic $\mathrm{GABA}_{\mathrm{A}}$ receptors have been found on GABAergic terminals targeting VTA DA neurons (Xiao et al., 2007). Also, immunohistochemical studies show that $\delta$-subunit is found in the VTA in neurons and neuronal processes (Pirker et al., 2000; Schwarzer et al., 2001) and a single-cell PCR and in situ hybridization study shows that the $\delta$-subunit is not found in the VTA DA neurons (Okada et al., 2004). Thus, THIP might act through activation of $\delta$-subunit-containing $\mathrm{GABA}_{\mathrm{A}}$ receptors on VTA GABAergic interneurons or GABAergic projection terminals on VTA DA neurons, which would lead to disinhibition of VTA DA neurons. This effect would then be similar to the effect of benzodiazepines that activate synaptic $\alpha 1 \gamma 2$ subunit-containing $\mathrm{GABA}_{\mathrm{A}}$ receptors on interneurons (Tan et al., 2010).

To test this idea, we examined whether THIP has an effect on VTA DA neurons in $\delta$-subunit-deficient mice (Mihalek et al., 1999) that are known to have reduced behavioral responses to THIP and other GABA site agonists (Chandra et al., 2006, 2010). In $\delta^{-l-}$ mice, THIP administration $(6 \mathrm{mg} / \mathrm{kg}) 24 \mathrm{~h}$ before preparing midbrain slices did not have an effect on AMPA/NMDA current ratio in the VTA DA neurons, in contrast to the increased ratio in littermate $\delta^{+/+}$mice (Fig. $7 A, B ; p<0.01$ ). The wild-type 
A

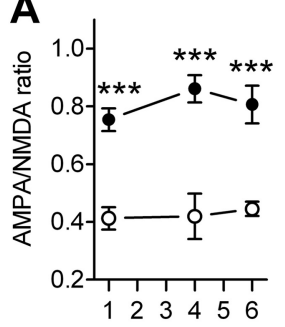

Time after THIP (days)

C
B

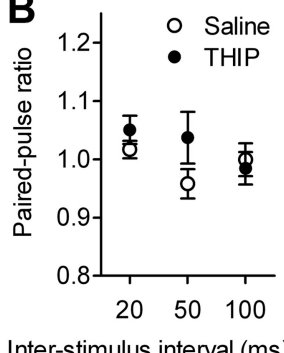

Inter-stimulus interval (ms)

THIP-treatment

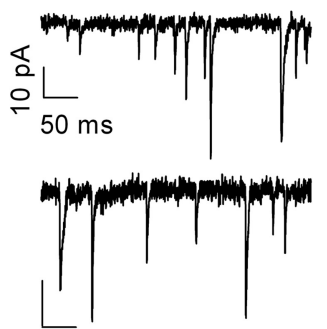

E

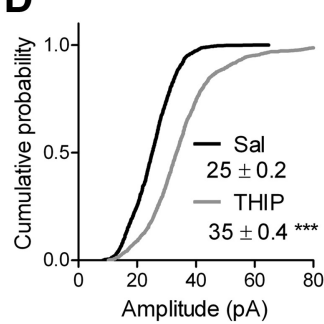

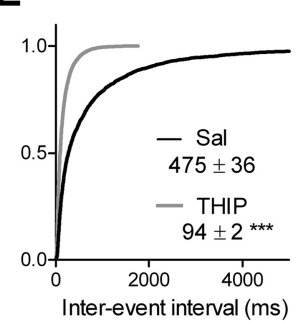

Figure 4. Time course and physiological mechanism of the glutamate receptor plasticity of VTA DA neurons after $6 \mathrm{mg} / \mathrm{kg}$ THIP exposure in Th-EGFP mice. $A$, Time course of the effects of saline and THIP administration on AMPA/NMDA ratio of VTA DA neurons is shown as means \pm SEM ( $n=5-7$, where $n$ is the number of tested animals) obtained 1, 4, and $6 \mathrm{~d}$ after the injection. The THIP effect was significant at least for $6 \mathrm{~d} .{ }^{* * *} p<0.001$, ANOVA with Bonferroni's test. $\boldsymbol{B}$, Paired-pulse ratios at various interstimulus intervals $(20,50$, and $100 \mathrm{~ms})$ showed no differences between saline- and THIP-treated groups $24 \mathrm{~h}$ after the treatments $(n=7-8)$. $C$, Examples of mEPSCs recorded at $-70 \mathrm{mV}$ from DA neurons obtained $24 \mathrm{~h}$ after saline and THIP treatments. Traces from two different animals are shown for both treatments. Calibration: 10 $\mathrm{pA} / 50 \mathrm{~ms}$. Cumulative probability plots for amplitudes $(\boldsymbol{D})$ and interevent intervals $(\boldsymbol{E})$ of the $\mathrm{mEPSC}$ recorded from the VTA DA neurons of saline- and THIP-treated animals $24 \mathrm{~h}$ after the treatments. The plots and the means \pm SEM $(n=8-9)$ given inside the plots for both treatments indicate that THIP increased the amplitude and the frequency compared with saline. ${ }^{* * *} p<0.001$, Mann-Whitney test.

littermate $\delta^{+/+}$mice demonstrated increased AMPA/NMDA ratios after THIP administration (Fig. $7 A, B ; p<0.01$ ), similarly to the transgenic Th-EGFP mice. Thus, even if in some transgenic BAC-EGFP mouse lines the DAergic system has been abnormally modified (Bagetta et al., 2011; Kramer et al., 2011), the EGFP labeling or mouse background line were not responsible for the THIP-induced plasticity in this study.

Intravenous self-administration of THIP in naive mice Since THIP treatment was associated with the development of glutamate receptor neuroplasticity in VTA DA neurons, it was important to test whether THIP would be reinforcing or rewarding in adult behaving mice. No such data exist in the literature to our knowledge. First, we studied whether THIP would acutely increase nose-poking behavior in naive mice. The results demonstrate that acute intravenous self-administration of THIP at dif-
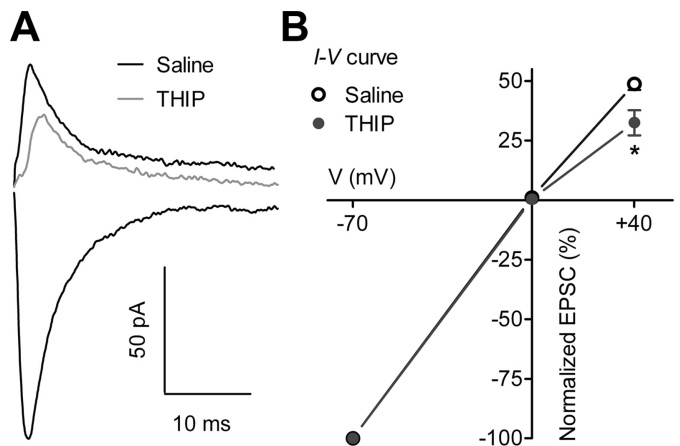

Figure 5. THIP treatment $(6 \mathrm{mg} / \mathrm{kg}$ ) triggered insertion of new GluA2-lacking AMPA receptors in the VTA DA neurons $24 \mathrm{~h}$ after the injection in Th-EGFP mice. $A$, Examples of traces recorded at -70 and $+40 \mathrm{mV}$ after saline and THIP treatments. $B$, Averaged $I-V$ plots of AMPA receptor-mediated currents in the VTA DA neurons of saline-treated $(n=6$, where $n$ is the number of tested animals) and THIP-treated $(n=6)$ animals. ${ }^{*} p<0.05$, Mann-Whitney test.
A

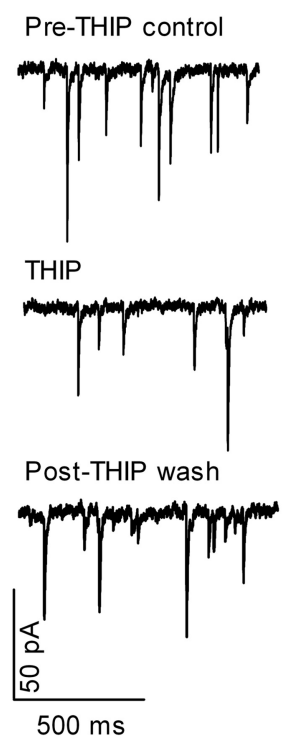

B
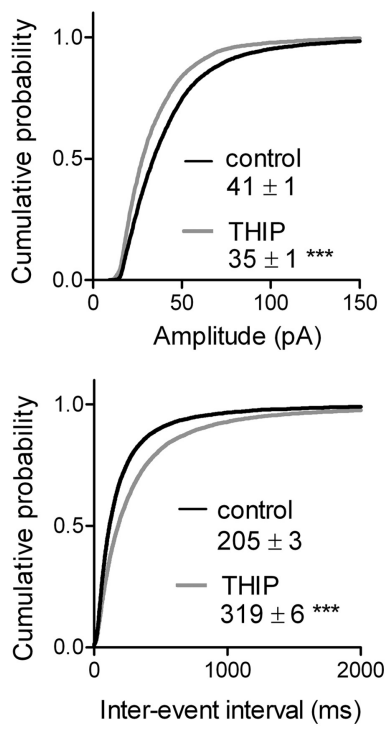

Figure 6. Reduced inhibitory input onto VTA DA neurons of midbrain slices by application of THIP in vitro. A, Example traces of SIPSC recordings obtained before (control), during, and after bath application (wash) of $1 \mu \mathrm{M}$ THIP. Calibration: 50 pA/500 ms. B, Cumulative probability plots for amplitudes and interevent intervals of the sIPSCs recorded from the VTA DA neurons before (control) and during bath application of THIP. THIP decreased sIPSC amplitudes and frequencies $(n=11)$. The insets show the means \pm SEM. ${ }^{* * *} p<0.001$, Mann-Whitney test. sIPSCS were abolished with picrotoxin (100 $\mu \mathrm{m}$ ) (data not shown).

ferent doses did not differ from that of saline (Fig. $8 A ; F_{(4,57)}=$ 2.23, $p=0.076)$. The THIP dose self-administered at the highest THIP concentration $(3 \mathrm{mg} / \mathrm{ml})$ corresponded well to the intraperitoneal dose of $6 \mathrm{mg} / \mathrm{kg}$ used in our electrophysiological and place conditioning experiments (Fig. $8 \mathrm{~B}$ ).

We also included another group of mice to test for the reinforcing capability of D-amphetamine $(0.5 \mathrm{mg} / \mathrm{ml})$ over saline as a positive control. The mice acquired a significant nose-poking behavior for D-amphetamine $(t=3.88, \mathrm{df}=42, p<0.001$; Fig. $8 A)$, as an indication of the reinforcing effect. Thus, the validity of the method was confirmed by the fact that the number of nose pokes of active and yoked control mice was not different when having an access to saline $(p>0.05)$, whereas the number of nose pokes of active mice with an access to D-amphetamine infusions selectively increased. 


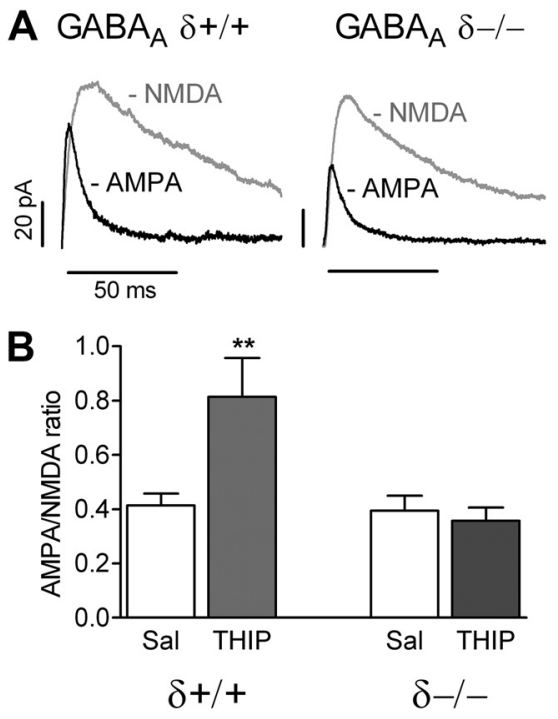

Figure 7. A single administration of $6 \mathrm{mg} / \mathrm{kg}$ THIP failed to evoke glutamate receptor plasticity in VTA DA neurons $24 \mathrm{~h}$ after the treatment in $\mathrm{GABA}_{\mathrm{A}}$ receptor $\delta^{-1-}$ mice. $A$, Representative examples of AMPA and NMDA receptor-mediated current traces after THIP treatment for wild-type littermate $\delta^{+/+}$mice and $\delta^{-/-}$mice. B, AMPA/NMDA receptor peak current ratios after saline and THIP treatments for $\delta^{+/+}$(saline, $n=6$, and THIP, $n=8$, where $n$ is the number of tested animals) and $\delta^{-1-}$ mice (saline, $n=6$, and THIP, $n=6$ ). Calibration: 20 $\mathrm{pA} / 50 \mathrm{~ms}$. Values are shown as means $+\mathrm{SEM} .{ }^{* *} p<0.01$, Mann-Whitney test.

\section{Intravenous self-administration in baboons}

All three baboons reliably self-administered the baseline dose of cocaine in the criterion range of six to eight self-injections per day for $3 \mathrm{~d}$ preceding substitution of test conditions (Fig. $8 C$ ); grand means ranged from 7.3 to 7.4 injections per day across baboons. Under the cocaine baseline procedure, the probability of selfinjection and, thus, experiencing the effects of the test condition is high in the first couple of days after substitution. Across the subsequent days, self-injection can stabilize (or a cyclical pattern can develop) and the rate of self-injection in the last 5 of $15 \mathrm{~d}$ is taken to represent the reinforcing efficacy of the dose compared with vehicle under the same conditions. When saline or THIP was made available at $0.1,0.18,0.32$, or $1.0 \mathrm{mg} \cdot \mathrm{kg}^{-1} \cdot$ injection $^{-1}$, self-injections on day 1 ranged from 2 to 5 across doses and baboons, and all baboons experienced the effects of THIP multiple times across the period of availability. By the last $5 \mathrm{~d}$ of availability, self-injection decreased and no dose of THIP maintained a significantly greater rate of self-injection than did saline in any baboon. That is, mean rate of THIP self-injection was not greater than the critical value of 2 SDs above the saline mean (values to be exceeded were 3.4, 4.0, and 2.4 injections per day for baboons CR, HC, and SI, respectively). Although blood analyses after intravenous THIP were not performed in the baboons in the present study, later assessment in four, comparably sized, adult male baboons found that THIP plasma concentrations increased dose-dependently and were highest at the time of the first sample, which was $\sim 5 \mathrm{~min}$ after the injection (N. A. Ator and B. Ebert, unpublished data). Values ranged, across baboons, from 0.53 to $1.24 \mu \mathrm{M}$ (mean, $0.85 \mu \mathrm{M}$ ) at $0.1 \mathrm{mg} / \mathrm{kg}$, from 3.1 to $4.3 \mu \mathrm{M}$ (mean, $3.5 \mu \mathrm{M}$ ) at $0.32 \mathrm{mg} / \mathrm{kg}$, and from 3.7 to $8.2 \mu \mathrm{M}$ (mean, $5.4 \mu \mathrm{M}$ ) at $1.0 \mathrm{mg} / \mathrm{kg}$, which suggests that relevant levels of compound were received in self-injections by the baboons in the present study.

For comparison of self-injection of another GABAergic compound to THIP in the baboons in the present study, data are presented for a known reinforcing dose $(0.01 \mathrm{mg} / \mathrm{kg})$ of the benzodiazepine triazolam (Fig. 8 C). In original study of triazolam in
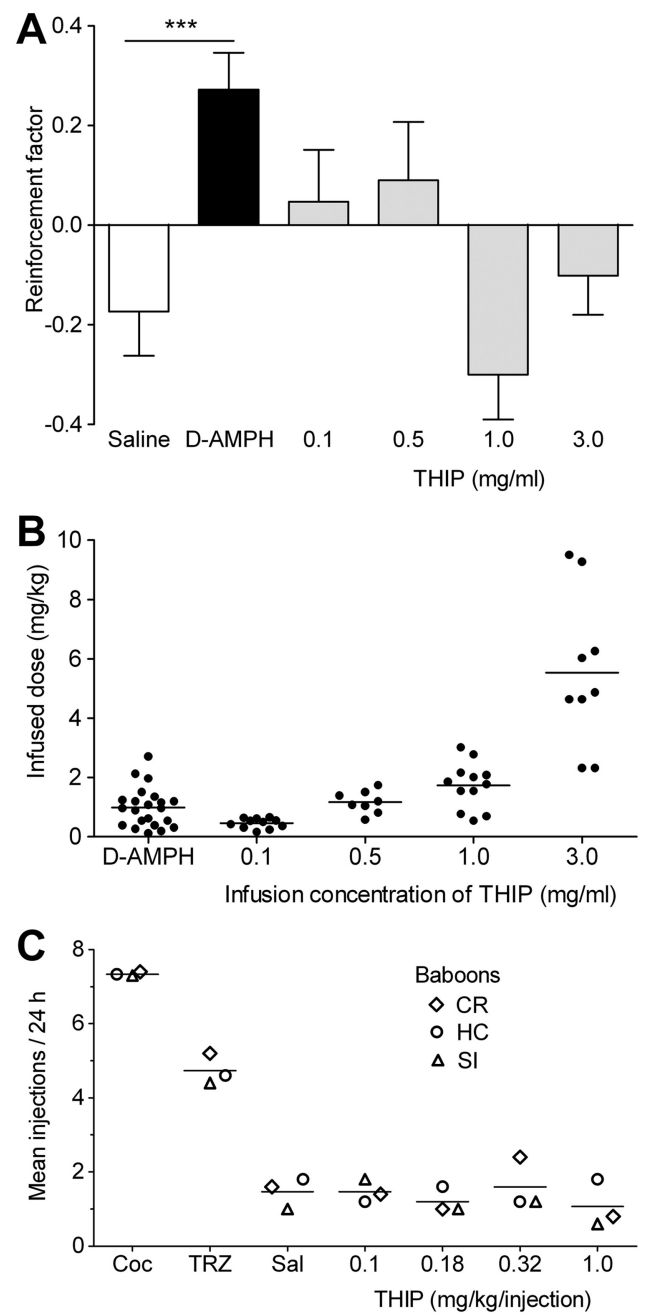

Figure 8. Intravenous self-administration of THIP in mice and baboons failed to indicate any reinforcing property for the drug. $\boldsymbol{A}$, Reinforcement scores for self-administration of different doses of THIP in C57BL/6J mice, with D-amphetamine as a positive control. Drug-naive adult mice were allowed to intravenously self-administer saline $(n=22$, where $n$ is the number of tested pairs of active and yoked-control mice $)$ or different doses of THIP $(0.1 \mathrm{mg} / \mathrm{ml}, n=11 ; 0.5$ $\mathrm{mg} / \mathrm{ml}, n=8 ; 1 \mathrm{mg} / \mathrm{ml}, n=12 ; 3 \mathrm{mg} / \mathrm{ml}, n=9)$ during 20 min sessions. A positive reinforcement factor indicates positive reinforcement. D-Amphetamine (D-AMPH) $(0.5 \mathrm{mg} / \mathrm{ml} ; n=22)$ induced significant self-administration. Data are means \pm SEM. ${ }^{* * *} p<0.001, t$ test. $\boldsymbol{B}$, Cluster plot with means depicting the cumulative intravenous doses of $D$-amphetamine and THIP during 20 min self-administration sessions under various infusion concentrations of THIP. Note that the total THIP dose at the infusion concentration of $3 \mathrm{mg} / \mathrm{ml}$ was at the same level as the THIP dose that was effective in intraperitoneal single dose experiments $(6 \mathrm{mg} / \mathrm{kg})$. C, Selfadministration of THIP in baboons $(n=3)$ with cocaine ( $\mathrm{Coc}$ ) and triazolam (TRZ) as positive controls. Sessions ran round the clock in the home cage; each intravenous self-injection was followed by a $3 \mathrm{~h}$ time-out limiting total per day to a maximum of 8 . Cocaine maintained $6-8$ injections per day on at least $3 \mathrm{~d}$ before each test condition; the grand means of the last $3 \mathrm{~d}$ before each test condition are shown for each baboon. Each dose of THIP and its vehicle, saline (Sal), were substituted for the baseline dose of cocaine $\left(0.32 \mathrm{mg} \cdot \mathrm{kg}^{-1} \cdot\right.$ injection $\left.^{-1}\right)$ as was triazolam $(0.01 \mathrm{mg} / \mathrm{kg}$ ) at a dose previously shown to be reinforcing in every baboon tested (see text) [TRZ means for (R and HC were published in the study by Ator (2000)]. Each TRZ, Sal, and THIP data point represents the mean of the number of self-injections on each of the last $5 \mathrm{~d}$ of the $15 \mathrm{~d}$ substitution period for each baboon. The horizontal lines indicate mean self-injection rate for the three baboons.

our laboratory, this dose maintained the highest mean rate of self-injection (5.6 injections per day; $n=4$ baboons), which was reinforcing compared with the triazolam vehicle (Griffiths et al., 1991). Triazolam $(0.01 \mathrm{mg} / \mathrm{kg})$ was studied in baboons CR and HC before the THIP study (Ator, 2000), and the results are shown 

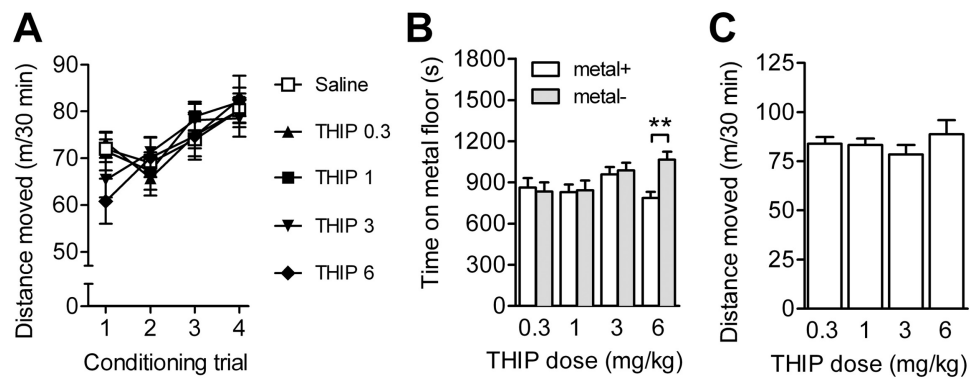

Figure 9. Place conditioning with THIP in adult C57BL/6J mice. $A$, Locomotor activity during each conditioning trial with various doses of THIP (CS+) and with saline (CS-) (saline trial data from all dose levels and conditioning subgroups were combined). Conditioning time for each saline and THIP trial was $30 \mathrm{~min}$. $\boldsymbol{B}$, Animals conditioned with THIP at the dose of $6 \mathrm{mg} / \mathrm{kg}$ expressed place aversion at $24 \mathrm{~h}$ after the last conditioning session, while those conditioned with the lower doses failed to express any preference or aversion. Test trial time after saline injection was $30 \mathrm{~min} .{ }^{* *} p<0.01, t$ test. C, Locomotor activity during test trials for various THIP dose groups. Data are presented as means \pm SEM. $n=5-14$.

in Figure $8 \mathrm{C}$ along with the results for this dose for baboon SI obtained at the end of the study of THIP. In the last $5 \mathrm{~d}$ of availability, all three baboons self-injected triazolam in the range of $4-6$ injections per day (mean rates were 4.4-5.2 injections per day; Fig. $8 C$ ). Although triazolam vehicle was not studied for baboon SI, triazolam reinforcement compared with vehicle could be concluded for baboons CR and HC (Ator, 2000).

\section{THIP-induced place conditioning}

The conditioned place preference test is often used to study the rewarding potential of drugs, and here we tested different doses of THIP in $4 \mathrm{~d}$ place conditioning tests. During the conditioning trials, no effect of THIP on locomotor activity was observed with any of the doses (dose and drug effects, $F_{(3,140)}=1.41, p>0.05$, and $F_{(1,140)}=0.231, p>0.05$, respectively; the first $6 \mathrm{mg} / \mathrm{kg}$ THIP dose tended to reduce activity; $p=0.063$ ). The trial factor was significant (trial effect, $F_{(3,420)}=19.27, p<0.001$ ), indicating that locomotor activity slightly changed over the conditioning trials in all groups. However, no significant interactions were observed between trial, dose, and drug. Locomotor activity during the conditioning trials is depicted in Figure $9 \mathrm{~A}$.

One day $(24 \mathrm{~h})$ after the conditioning trials, expression of THIP-conditioned place preference/avoidance was tested after saline administration. Only the mice conditioned with the THIP dose of $6 \mathrm{mg} / \mathrm{kg}$ expressed place conditioning (dose by conditioning subgroup interaction, $\left.F_{(3,65)}=3.345, p=0.024\right)$. However, these THIP-conditioned animals expressed place aversion, not preference (Fig. 9B). Test trial locomotor activity (Fig. 9C) was similar after conditioning with all THIP doses (dose effect, $\left.F_{(3,69)}=0.592, p>0.05\right)$.

To find out whether the observed aversive conditioning was persistent over time, the test trial was repeated at two later time points. Both at 11 and $30 \mathrm{~d}$ after the initial place conditioning test, the mice that were conditioned with $6 \mathrm{mg} / \mathrm{kg}$ THIP kept expressing robust place aversion [11 d: conditioning metal+ subgroup, $799 \pm 187 \mathrm{~s}, n=9$; metal - subgroup, $1114 \pm 269 \mathrm{~s}, n=9(t=$ $2.89, \mathrm{df}=16, p=0.011) ; 30 \mathrm{~d}$ : metal + subgroup, $817 \pm 247 \mathrm{~s}$, $n=9$; metal - subgroup, $1119 \pm 148 \mathrm{~s}, n=9(t=2.96, \mathrm{df}=16$, $p=0.010)]$.

\section{Discussion}

Glutamate receptor neuroplasticity in VTA DA neurons has been recently strongly linked to effects of various drugs of abuse (Lüscher and Ungless, 2006), including the benzodiazepines (Heikkinen et al., 2009; Tan et al., 2010). Here, we extend this list

\section{Mechanisms of THIP-induced glutamate receptor plasticity}

The THIP-sensitive benzodiazepine-insensitive extrasynaptic $\mathrm{GABA}_{\mathrm{A}}$ receptors are composed of $\alpha-, \beta$, and $\delta$-subunits, whereas synaptic benzodiazepine-sensitive receptors usually harbor $\alpha \beta \gamma 2$ receptors (Farrant and Nusser, 2005; Korpi and Sinkkonen, 2006; Glykys and Mody, 2007). Our findings here show that the effects of THIP on DA neurons were dependent on activation of $\alpha \beta \delta$ receptors since they were absent in $\delta$-subunitdeficient mice.

Glutamate receptor neuroplasticity in VTA DA neurons can be induced by activation of these neurons by various mechanisms (Lüscher and Ungless, 2006). Even engineered light-sensitive excitatory channels on DA neurons can serve for the induction of this neuroplasticity (Brown et al., 2010) and lead to conditioned place preference in mice (Tsai et al., 2009). The mechanisms also include indirect ones, such as inhibition of GABAergic interneurons, leading to disinhibition of DA neurons. This has been shown for benzodiazepines acting through $\alpha 1 \beta \gamma 2 \mathrm{GABA}_{\mathrm{A}}$ receptors (Tan et al., 2010) and for opioids acting via $\mu$-opioid receptors (Johnson and North, 1992; Saal et al., 2003; Heikkinen et al., 2009). Importantly, $\delta$-subunit-containing receptors exist in VTA GABAergic interneurons (Pirker et al., 2000; Okada et al., 2004; Xiao et al., 2007), providing a route for disinhibition of DA neurons by THIP, too. This hypothesis was supported by THIP reducing both the frequency and amplitude of spontaneous $\mathrm{GABA}_{\mathrm{A}}$ receptor-mediated IPSCs of VTA DA neurons in perfused midbrain slices (Fig. 6). The disinhibition hypothesis is also consistent with increased firing of DA neurons in vivo by intravenous THIP (Waszczak and Walters, 1980). Here, we propose that the activation of DA neurons by in vivo THIP treatment induced insertion of new GluA2-subunit-lacking AMPA receptors, as shown by increased rectification of AMPA currents at positive holding potentials and increased frequency and amplitudes of AMPA mEPSCs (Fig. 4). Paired-pulse ratios were not changed, and, therefore, the results suggest a postsynaptic enhancement of AMPA responses (Citri and Malenka, 2008). Buildup of novel spines might explain these findings, as has been suggested for cocaine-induced neuroplasticity (Sarti et al., 2007). Further study is still warranted on detailed mechanisms of THIP effects on various types of neurons.

\section{Lack of rewarding effects of THIP in mice and baboons}

We initially predicted that THIP would show potential for rewarding behavioral effects. Benzodiazepines induce preference 
for a place previously associated with their effects in rodents (Spyraki et al., 1985; Imaizumi et al., 2000); and in rats, diazepam-induced place preference can be prevented by an AMPA receptor antagonist (Gray et al., 1999). However, THIP demonstrated an opposite effect, as it induced a long-lasting conditioned place aversion. We used an unbiased conditioning procedure to eliminate possible interference of anxiety and anxiolysis during the test (File, 1986; Parker et al., 1998), although THIP has poor anxiolytic efficacy in wild-type mice (Saarelainen et al., 2008). Although changes in the locomotor activity could have interfered with the expression of place preference (Gremel and Cunningham, 2007), this is unlikely because the locomotor activity during the tests was similar for the low-dose groups not showing aversion or preference and for the highest dose $(6 \mathrm{mg} / \mathrm{kg})$ group showing aversion. Consistent with a pharmacological dose-response, THIP doses $<6$ $\mathrm{mg} / \mathrm{kg}$ failed to induce any significant glutamate receptor plasticity (Fig. 2) or aversion compared with saline (Fig. 9). THIPinduced sedation was not sufficient for the neuroplasticity since 3 and $6 \mathrm{mg} / \mathrm{kg}$ doses induced similar sedation in young mice (Fig. 1), and the adult mice showed little sedation even at the highest dose (Fig. 9A).

THIP also failed to induce intravenous self-administration in naive mice and in baboons experienced in drug selfadministration (Fig. 8). Importantly, the mice increased their nose-poking responses that produced D-amphetamine, confirming reinforcement by the stimulant and serving as a positive control for the assay using yoked control mice. This approach in mice is considered to be valid for initial drug screening of abuse liability (Criswell and Ridings, 1983; Kuzmin et al., 2000). Similarly when nonhuman primates, baboons, were provided the opportunity to self-administer THIP under a procedure that has been a standard for assessing reinforcing effects of novel, centrally acting compounds (Griffiths et al., 1991; Ator and Griffiths, 2003; Ator et al., 2010), no evidence for THIP reinforcement was obtained, while responding for cocaine and the benzodiazepine triazolam was evident. Our results thus support the idea that THIP has little, if any, behaviorally rewarding efficacy.

\section{Role of neuroplasticity of VTA DA neurons in rewarding and aversive responding}

It remains unclear whether the VTA DA neuron plasticity induces further plasticity in other neuronal populations of the circuitry, such as neurons in the nucleus accumbens, and leads to behavioral changes underlying chronic addiction (Lüscher and Malenka, 2011). There are contradictory results from several studies attempting to link VTA plasticity with behavioral sensitization or conditioned place preference (Harris et al., 2004; Dunn et al., 2005; Engblom et al., 2008; Panhelainen et al., 2011). Administration of AMPA directly into the VTA does not induce conditioned place preference, but produces conditioned aversion within the anterior (rostral) VTA (Ikemoto et al., 2004). Opposite results suggesting that modulation of the posterior (caudal) VTA leads to conditioned aversion have been reported (Olson et al., 2005; Brischoux et al., 2009; Lammel et al., 2011). Interestingly, in mice, different VTA DA neurons respond to rewarding and aversive stimuli (Lammel et al., 2011). Hence rewarding stimuli may exclusively modify those DA neurons projecting to the medial shell of the nucleus accumbens, while aversive stimuli might selectively modify a distinct population of DA neurons projecting to the medial prefrontal cortex (Lammel et al., 2011). Since we used Th-EGFP labeling to identify DA neurons, we studied a neuronal population with mixed projection targets (e.g., to striatal, limbic, and cortical areas). Our analysis with respect to the location of the DA neurons recorded did not reveal any difference in THIP-induced glutamate receptor plasticity in either dorsoventral or rostrocaudal dimension of the VTA (Fig. 3). However, this was done in a post hoc manner, with most recorded neurons being close to the VTA center; but our data indicated large neuron-to-neuron variability in THIP-induced plasticity (Fig. 3), and, therefore, it cannot be fully excluded that THIP would affect only a specific aversion-responsive DA neuron population.

It is possible that the behavioral effects of THIP are mediated also by other brain regions than VTA, possibly by brain areas important for aversion. Various aversive behaviors induce c-Fos immunoreactivity as a marker of neuronal activity in amygdala, pontine parabrachial nucleus, medial prefrontal cortex, VTA, and ventral hippocampus (Ma et al., 1993; Navarro et al., 2000; Valenti et al., 2011). However, the primary targets of THIP might also be the ones with the highest densities of $\delta$-subunit-containing $\mathrm{GABA}_{\mathrm{A}}$ receptors, such as the thalamus, hippocampus, and cerebellum (Korpi and Sinkkonen, 2006; Belelli et al., 2009). The effect of THIP on VTA DA neurons lasted at least $6 \mathrm{~d}$, and the conditioned aversion induced by four repeated THIP administrations lasted longer than 1 month. Therefore, THIP might have induced persistent neuroplasticity in a number of brain regions in addition to the VTA.

THIP has been tested in several clinical studies for insomnia, being well tolerated and showing efficacy in promoting sleep maintenance (Walsh et al., 2008; Hajak et al., 2009; Roth et al., 2010). However, it was not submitted for regulatory approval due to variable efficacy in primary insomnia and because of increased psychiatric side effects at high doses in a small group of drug abusers (http://www.firstwordplus.com/Fws. do?articleid=BD22D048CEDD423FA137C73120BA75D8). Our results suggest that, without efficacy problems, THIP might have made an excellent therapeutic due to its low addiction potential. Addiction is the most serious adverse effect of the commonly used benzodiazepines (O'Brien, 2005). It remains to be studied whether THIP-induced plasticity affects the rewarding effects of other drugs of abuse.

In summary, we report here that a preferential extrasynaptic $\mathrm{GABA}_{\mathrm{A}}$ receptor activator THIP (gaboxadol) induces neuroplasticity changes in midbrain dopamine neurons similar to benzodiazepines and other drugs of abuse. However, THIP produced persistent aversive place conditioning and did not maintain selfadministration in either mice or baboons. The present results might help to dissect brain pathways or perhaps specific DA projections that are essential for addictive, reinforcing, and aversive behaviors.

\section{References}

Argilli E, Sibley DR, Malenka RC, England PM, Bonci A (2008) Mechanism and time course of cocaine-induced long-term potentiation in the ventral tegmental area. J Neurosci 28:9092-9100.

Ator NA (2000) Zaleplon and triazolam: drug discrimination, plasma levels, and self-administration in baboons. Drug Alcohol Depend 61:55-68.

Ator NA, Griffiths RR (2003) Principles of drug abuse liability assessment in laboratory animals. Drug Alcohol Depend 70:S55-S72.

Ator NA, Atack JR, Hargreaves RJ, Burns HD, Dawson GR (2010) Reducing abuse liability of $\mathrm{GABA}_{\mathrm{A}}$ /benzodiazepine ligands via selective partialagonist efficacy at $\alpha 1$ and $\alpha 2 / 3$ subtypes. J Pharmacol Exp Ther 332:4-16.

Bagetta V, Picconi B, Marinucci S, Sgobio C, Pendolino V, Ghiglieri V, Fusco FR, Giampà C, Calabresi P (2011) Dopamine-dependent long-term depression is expressed in striatal spiny neurons of both direct and indirect pathways: implications for Parkinson's disease. J Neurosci 31:12513-12522.

Belelli D, Harrison NL, Maguire J, Macdonald RL, Walker MC, Cope DW 
(2009) Extrasynaptic $\mathrm{GABA}_{\mathrm{A}}$ receptors: form, pharmacology, and function. J Neurosci 29:12757-12763.

Bellone C, Lüscher C (2006) Cocaine triggered AMPA receptor redistribution is reversed in vivo by mGluR-dependent long-term depression. Nat Neurosci 9:636-641.

Borgland SL, Malenka RC, Bonci A (2004) Acute and chronic cocaineinduced potentiation of synaptic strength in the ventral tegmental area: electrophysiological and behavioral correlates in individual rats. J Neurosci 24:7482-7490.

Bowers MS, Chen BT, Bonci A (2010) AMPA receptor synaptic plasticity induced by psychostimulants: the past, present, and therapeutic future. Neuron 67:11-24.

Brischoux F, Chakraborty S, Brierley DI, Ungless MA (2009) Phasic excitation of dopamine neurons in ventral VTA by noxious stimuli. Proc Natl Acad Sci U S A 106:4894-4899.

Brown MT, Bellone C, Mameli M, Labouèbe G, Bocklisch C, Balland B, Dahan L, Luján R, Deisseroth K, Lüscher C (2010) Drug-driven AMPA receptor redistribution mimicked by selective dopamine neuron stimulation. PLoS One 5:e15870.

Brown N, Kerby J, Bonnert TP, Whiting PJ, Wafford KA (2002) Pharmacological characterization of a novel cell line expressing human $\alpha 4 \beta 3 \delta$ $\mathrm{GABA}_{\mathrm{A}}$ receptors. Br J Pharmacol 136:965-974.

Chandra D, Jia F, Liang J, Peng Z, Suryanarayanan A, Werner DF, Spigelman I, Houser CR, Olsen RW, Harrison NL, Homanics GE (2006) GABA receptor $\alpha 4$ subunits mediate extrasynaptic inhibition in thalamus and dentate gyrus and the action of gaboxadol. Proc Natl Acad Sci U S A 103:15230-15235.

Chandra D, Halonen LM, Linden AM, Procaccini C, Hellsten K, Homanics GE, Korpi ER (2010) Prototypic $\mathrm{GABA}_{\mathrm{A}}$ receptor agonist muscimol acts preferentially through forebrain high-affinity binding sites. Neuropsychopharmacology 35:999-1007.

Citri A, Malenka RC (2008) Synaptic plasticity: multiple forms, functions, and mechanisms. Neuropsychopharmacology 33:18-41.

Cremers T, Ebert B (2007) Plasma and CNS concentrations of gaboxadol in rats following subcutaneous administration. Eur J Pharmacol 562:47-52.

Criswell HE, Ridings A (1983) Intravenous self-administration of morphine by naive mice. Pharmacol Biochem Behav 18:467-470.

Cunningham CL, Gremel CM, Groblewski PA (2006) Drug-induced conditioned place preference and aversion in mice. Nat Protoc 1:1662-1670.

Dingledine R, Borges K, Bowie D, Traynelis SF (1999) The glutamate receptor ion channels. Pharmacol Rev 51:7-61.

Dunn JM, Inderwies BR, Licata SC, Pierce RC (2005) Repeated administration of AMPA or a metabotropic glutamate receptor agonist into the rat ventral tegmental area augments the subsequent behavioral hyperactivity induced by cocaine. Psychopharmacology (Berl) 179:172-180.

Engblom D, Bilbao A, Sanchis-Segura C, Dahan L, Perreau-Lenz S, Balland B, Parkitna JR, Luján R, Halbout B, Mameli M, Parlato R, Sprengel R, Lüscher C, Schütz G, Spanagel R (2008) Glutamate receptors on dopamine neurons control the persistence of cocaine seeking. Neuron 59:497-508

Farrant M, Nusser Z (2005) Variations on an inhibitory theme: phasic and tonic activation of $\mathrm{GABA}_{\mathrm{A}}$ receptors. Nat Rev Neurosci 6:215-229.

File SE (1986) Aversive and appetitive properties of anxiogenic and anxiolytic agents. Behav Brain Res 21:189-194.

Franklin KBJ, Paxinos G (2008) The mouse brain in stereotaxic coordinates, Ed 3. Amsterdam: Elsevier.

Glykys J, Mody I (2007) Activation of GABA $\mathrm{A}_{\mathrm{A}}$ receptors: views from outside the synaptic cleft. Neuron 56:763-770.

Gong S, Zheng C, Doughty ML, Losos K, Didkovsky N, Schambra UB, Nowak NJ, Joyner A, Leblanc G, Hatten ME, Heintz N (2003) A gene expression atlas of the central nervous system based on bacterial artificial chromosomes. Nature 425:917-925.

Gray A, Allison C, Pratt JA (1999) A role for AMPA/kainate receptors in conditioned place preference induced by diazepam in the rat. Neurosci Lett 268:127-130.

Gremel CM, Cunningham CL (2007) Role of test activity in ethanolinduced disruption of place preference expression in mice. Psychopharmacology (Berl) 191:195-202.

Griffiths RR, Lamb RJ, Sannerud CA, Ator NA, Brady JV (1991) Selfinjection of barbiturates, benzodiazepines, and other sedative anxiolytics in baboons. Psychopharmacology 103:154-161.

Hajak G, Hedner J, Eglin M, Loft H, Stórustovu SI, Lütolf S, Lundahl J;
Gaboxadol Study 99775 Group (2009) A 2-week efficacy and safety study of gaboxadol and zolpidem using electronic diaries in primary insomnia outpatients. Sleep Med 10:705-712.

Harris GC, Wimmer M, Byrne R, Aston-Jones G (2004) Glutamate-associated plasticity in the ventral tegmental area is necessary for conditioning environmental stimuli with morphine. Neuroscience 129:841-847.

Heikkinen AE, Möykkynen TP, Korpi ER (2009) Long-lasting modulation of glutamatergic transmission in VTA dopamine neurons after a single dose of benzodiazepine agonists. Neuropsychopharmacology 34:290-298.

Hyman SE (2005) Addiction: a disease of learning and memory. Am J Psychiatry 162:1414-1422.

Ikemoto S, Witkin BM, Zangen A, Wise RA (2004) Rewarding effects of AMPA administration into the supramammillary or posterior hypothalamic nuclei but not the ventral tegmental area. J Neurosci 24:5758-5765.

Imaizumi M, Takeda M, Fushiki T (2000) Effects of oil intake in the conditioned place preference test in mice. Brain Res 870:150-156.

Johnson SW, North RA (1992) Opioids excite dopamine neurons by hyperpolarization of local interneurons. J Neurosci 12:483-488.

Kauer JA, Malenka RC (2007) Synaptic plasticity and addiction. Nat Rev Neurosci 8:844-858.

Korpi ER, Sinkkonen ST (2006) $\mathrm{GABA}_{\mathrm{A}}$ receptor subtypes as targets for neuropsychiatric drug development. Pharmacol Ther 109:12-32.

Kramer PF, Christensen CH, Hazelwood LA, Dobi A, Bock R, Sibley DR, Mateo Y, Alvarez VA (2011) Dopamine $\mathrm{D}_{2}$ receptor overexpression alters behavior and physiology in Drd2-EGFP mice. J Neurosci 31:126-132.

Krogsgaard-Larsen P, Frølund B, Liljefors T, Ebert B (2004) $\mathrm{GABA}_{\mathrm{A}}$ agonists and partial agonists: THIP (gaboxadol) as a non-opioid analgesic and a novel type of hypnotic. Biochem Pharmacol 68:1573-1580.

Kuzmin AV, Patkina NA, Zvartau EE (1994) Analgesic and reinforcing effects of morphine in mice. Influence of Bay K-8644 and nimodipine. Brain Res 652:1-8.

Kuzmin AV, Gerrits MA, Zvartau EE, van Ree JM (2000) Influence of buprenorphine, butorphanol and nalbuphine on the initiation of intravenous cocaine self-administration in drug naive mice. Eur Neuropsychopharmacol 10:447-454.

Lammel S, Hetzel A, Häckel O, Jones I, Liss B, Roeper J (2008) Unique properties of mesoprefrontal neurons within a dual mesocorticolimbic dopamine system. Neuron 57:760-773.

Lammel S, Ion DI, Roeper J, Malenka RC (2011) Projection-specific modulation of dopamine neuron synapses by aversive and rewarding stimuli. Neuron 70:855-862.

Lüscher C, Malenka RC (2011) Drug-evoked synaptic plasticity in addiction: from molecular changes to circuit remodeling. Neuron 69:650-663.

Lüscher C, Ungless MA (2006) The mechanistic classification of addictive drugs. PLoS Med 3:e437.

Ma QP, Zhou Y, Han JS (1993) Noxious stimulation accelerated the expression of c-fos protooncogene in cholecystokininergic and dopaminergic neurons in the ventral tegmental area. Peptides 14:561-566.

Mallart A, Martin AR (1968) The relation between quantum content and facilitation at the neuromuscular junction of the frog. J Physiol 196:593-604.

Mameli M, Bellone C, Brown MT, Lüscher C (2011) Cocaine inverts rules for synaptic plasticity of glutamate transmission in the ventral tegmental area. Nat Neurosci 14:414-416.

Maren S, Fanselow MS (1995) Synaptic plasticity in the basolateral amygdala induced by hippocampal formation stimulation in vivo. J Neurosci 15:7548-7564.

Margolis EB, Lock H, Hjelmstad GO, Fields HL (2006) The ventral tegmental area revisited: is there an electrophysiological marker for dopaminergic neurons? J Physiol 577:907-924.

Mihalek RM, Banerjee PK, Korpi ER, Quinlan JJ, Firestone LL, Mi ZP, Lagenaur C, Tretter V, Sieghart W, Anagnostaras SG, Sage JR, Fanselow MS, Guidotti A, Spigelman I, Li Z, DeLorey TM, Olsen RW, Homanics GE (1999) Attenuated sensitivity to neuroactive steroids in $\gamma$-aminobutyrate type A receptor $\delta$ subunit knockout mice. Proc Natl Acad Sci U S A 96:12905-12910.

Navarro M, Spray KJ, Cubero I, Thiele TE, Bernstein IL (2000) cFos induction during conditioned taste aversion expression varies with aversion strength. Brain Res 887:450-453.

Nestler EJ (2005) Is there a common molecular pathway for addiction? Nat Neurosci 8:1445-1449. 
Nugent FS, Penick EC, Kauer JA (2007) Opioids block long-term potentiation of inhibitory synapses. Nature 446:1086-1090.

Nuutinen S, Karlstedt K, Aitta-Aho T, Korpi ER, Panula P (2010) Histamine and $\mathrm{H} 3$ receptor-dependent mechanisms regulate ethanol stimulation and conditioned place preference in mice. Psychopharmacology (Berl) 208:75-86.

O’Brien CP (2005) Benzodiazepine use, abuse, and dependence. J Clin Psychiatry 66 [Suppl 2]:28-33.

Okada H, Matsushita N, Kobayashi K, Kobayashi K (2004) Identification of $\mathrm{GABA}_{\mathrm{A}}$ receptor subunit variants in midbrain dopaminergic neurons. J Neurochem 89:7-14.

Olson VG, Zabetian CP, Bolanos CA, Edwards S, Barrot M, Eisch AJ, Hughes T, Self DW, Neve RL, Nestler EJ (2005) Regulation of drug reward by cAMP response element-binding protein: evidence for two functionally distinct subregions of the ventral tegmental area. J Neurosci 25:5553-5562.

Panhelainen AE, Vekovischeva OY, Aitta-Aho T, Rasanen I, Ojanperä I, Korpi ER (2011) Diazepam-induced neuronal plasticity attenuates locomotor responses to morphine and amphetamine challenges in mice. Neuroscience 192:312-321.

Parker LA, Limebeer CL, Simpson GR (1998) Chlordiazepoxide-induced conditioned place and taste aversion learning in rats. Pharmacol Biochem Behav 59:33-37.

Pastalkova E, Serrano P, Pinkhasova D, Wallace E, Fenton AA, Sacktor TC (2006) Storage of spatial information by the maintenance mechanism of LTP. Science 313:1141-1144.

Pirker S, Schwarzer C, Wieselthaler A, Sieghart W, Sperk G (2000) GABA A receptors: immunocytochemical distribution of 13 subunits in the adult rat brain. Neuroscience 101:815-850.

Roth T, Lines C, Vandormael K, Ceesay P, Anderson D, Snavely D (2010) Effect of gaboxadol on patient-reported measures of sleep and waking function in patients with primary insomnia: results from two randomized, controlled, 3-month studies. J Clin Sleep Med 6:30-39.

Saal D, Dong Y, Bonci A, Malenka RC (2003) Drugs of abuse and stress trigger a common synaptic adaptation in dopamine neurons. Neuron 37:577-582.

Saarelainen KS, Ranna M, Rabe H, Sinkkonen ST, Möykkynen T, Uusi-Oukari M, Linden AM, Lüddens H, Korpi ER (2008) Enhanced behavioral sensitivity to the competitive GABA agonist, gaboxadol, in transgenic mice overexpressing hippocampal extrasynaptic $\alpha 6 \beta \mathrm{GABA}_{\mathrm{A}}$ receptors. J Neurochem 105:338-350.

Sarti F, Borgland SL, Kharazia VN, Bonci A (2007) Acute cocaine exposure alters spine density and long-term potentiation in the ventral tegmental area. Eur J Neurosci 26:749-756.

Schultz W, Dayan P, Montague PR (1997) A neural substrate of prediction and reward. Science 275:1593-1599.

Schwarzer C, Berresheim U, Pirker S, Wieselthaler A, Fuchs K, Sieghart W, Sperk G (2001) Distribution of the major $\gamma$-aminobutyric acid $_{\mathrm{A}}$ recep- $^{-}$ tor subunits in the basal ganglia and associated limbic brain areas of the adult rat. J Comp Neurol 433:526-549.

Spyraki C, Kazandjian A, Varonos D (1985) Diazepam-induced place pref- erence conditioning: appetitive and antiaversive properties. Psychopharmacology (Berl) 87:225-232.

Stórustovu SI, Ebert B (2006) Pharmacological characterization of agonists at $\delta$-containing $\mathrm{GABA}_{\mathrm{A}}$ receptors: functional selectivity for extrasynaptic receptors is dependent on the absence of $\gamma 2$. J Pharmacol Exp Ther 316:1351-1359.

Stuber GD, Klanker M, de Ridder B, Bowers MS, Joosten RN, Feenstra MG, Bonci A (2008) Reward-predictive cues enhance excitatory synaptic strength onto midbrain dopamine neurons. Science 321:1690-1692.

Tan KR, Brown M, Labouèbe G, Yvon C, Creton C, Fritschy JM, Rudolph U, Lüscher C (2010) Neural bases for addictive properties of benzodiazepines. Nature 463:769-774.

Tsai HC, Zhang F, Adamantidis A, Stuber GD, Bonci A, de Lecea L, Deisseroth K (2009) Phasic firing in dopaminergic neurons is sufficient for behavioral conditioning. Science 324:1080-1084.

Ungless MA, Whistler JL, Malenka RC, Bonci A (2001) Single cocaine exposure in vivo induces long-term potentiation in dopamine neurons. Nature 411:583-587.

Valenti O, Lodge DJ, Grace AA (2011) Aversive stimuli alter ventral tegmental area dopamine neuron activity via a common action in the ventral hippocampus. J Neurosci 31:4280-4289.

Vekovischeva OY, Semenova SG, Verbitskaya EV, Zvartau EE (2004) Effects of morphine and cocaine in mice with stable high aggressive and nonaggressive behavioral strategy. Pharmacol Biochem Behav 77:235-243.

Walsh JK, Mayleben D, Guico-Pabia C, Vandormael K, Martinez R, Deacon S (2008) Efficacy of the selective extrasynaptic GABA $\mathrm{A}_{\mathrm{A}}$ agonist, gaboxadol, in a model of transient insomnia: a randomized, controlled clinical trial. Sleep Med 9:393-402.

Waszczak BL, Walters JR (1980) Intravenous GABA agonist administration stimulates firing of A10 dopaminergic neurons. Eur J Pharmacol 66:141-144.

Wei W, Zhang N, Peng Z, Houser CR, Mody I (2003) Perisynaptic localization of $\delta$ subunit-containing $\mathrm{GABA}_{\mathrm{A}}$ receptors and their activation by GABA spillover in the mouse dentate gyrus. J Neurosci 23:10650-10661.

White FJ (1996) Synaptic regulation of mesocorticolimbic dopamine neurons. Annu Rev Neurosci 19:405-436.

Whitlock JR, Heynen AJ, Shuler MG, Bear MF (2006) Learning induces long-term potentiation in the hippocampus. Science 313:1093-1097.

Wise RA (2008) Dopamine and reward: the anhedonia hypothesis 30 years on. Neurotox Res 14:169-183.

Wise RA, Bozarth MA (1987) A psychomotor stimulant theory of addiction. Psychol Med 94:469-492.

Wolf ME (1998) The role of excitatory amino acids in behavioral sensitization to psychomotor stimulants. Prog Neurobiol 54:679-720.

Xiao C, Zhou C, Li K, Ye JH (2007) Presynaptic GABA receptors facilitate GABAergic transmission to dopaminergic neurons in the ventral tegmental area of young rats. J Physiol 580:731-743.

Zhang N, Wei W, Mody I, Houser CR (2007) Altered localization of GABA receptor subunits on dentate granule cell dendrites influences tonic and phasic inhibition in a mouse model of epilepsy. J Neurosci 27:7520-7531. 